\title{
Religiosity and Subjective Well-Being among Older Adults: A Systematic Review
}

\author{
Sumara Masood Ul Hassan \\ Department of Behavioral Sciences, S3H, National University of Sciences and Technology, H12, \\ Islamabad, Pakistan \\ Email: dr.sumara@s3h.nust.edu.pk
}

\begin{abstract}
Purpose: Religiosity acts as a protective agent against the trajectories of ill-being in the later stage of life. The current systematic review aimed to identify and critically evaluate available literature regarding the association between religiosity and subjective well-being. Methodology: Studies were sourced from Google Scholar, Science Direct and Pubmed, published between 2011 and 2017. The eligibility criteria for the selected articles was: subjective well-being as an outcome variable, participants aged 60 and above, studies having cross-sectional/comparative, cohort/longitudinal, qualitative, or quantitative research designs, and published in the English language. Findings: After the screening and quality assessment through STROBE and SIGN checklists, a synthesis of 7 out of 77 articles were accumulated. Equivocal patterns of association were observed between religiosity and subjective well-being. It was also found that different dimensions of religiosity exerted positive and negative influences on the subjective well-being of the older adults. Implications: Therefore, focus on the empirical connections between religiosity and subjective well-being will enhance professionals' knowledge regarding the literature gaps and underlying pathways. It also provides the direction for future studies.
\end{abstract}

Keywords: Religiosity; Subjective Well-Being; Older Adults.

\section{INTRODUCTION}

In recent times, growing evidence has been identified in the study of successful aging due to the rapid growth of the greying population. Declining fertility and increasing life expectancy are two major contributing factors to worldwide population aging. According to the United Nations (2017), the global share of adults (aged 60 and above) is $13 \%$ of the total population, is expected to reach from 962 million to 2.1 billion by the year 2050. This rising number of older population is expected to offer fresh challenges to the health and well-being of the older adults. Well-being is significantly important in old age as in other developmental stages. World Health Organization (2016) indicated that approximately $15 \%$ of adults aged 60 and above are suffering from mental health problems worldwide. Hence, gerontologist should focus on the contributing factors that help older adults to boost their sense of mental health and well-being when confronted with old age trajectories.

Subjective well-being of older adults is a cornerstone of the healthy aging and quality of life (Herero \& Extremera, 2010; Peterson, Chatters, Taylor, \& Nguyen, 2014; Tu \& Yang, 2016). It is considered as an important ingredient of a happy life which tends to protect aged individuals from maladaptive functioning (Myer \& Diener, 1995). It is broadly conceptualized as an individual's positive appraisal of his/her life and emotional reactions to an event (Diener, 1984; Diener, Oishi, \& Lucas, 2002). Herero and Extremera (2010) stated that subjective well-being consisted of two components namely; cognitive and affect. Cognitive domain of subjective well-being comprised of life satisfaction (i.e., cognitive judgment of satisfaction and fulfillment). The affective domain is characterized by positive affect (i.e., positive mood such as joy, happiness, and contentment) and negative affect (i.e., negative emotional reactions such as sadness, guilt, and shame).

Religiosity has been identified as a significant predictor of well-being in the majority of older adults' samples. Studies explained that religion acts as a protective agent against the trajectories of ill-being (Ronneberg, Miller, Dugan \& Porell, 2016) and enables the individual to cope effectively with the stressful transitions of the later life (Momtaz, Hamid, Ibrahim, Yahaya, \& Abdullah, 2012). The concept is defined as a practice involves activities such as praying, attending religious services and finding values in religious beliefs (Gunnoe \& Moore, 2002), was 
positively associated with subjective well-being (Krause, 2003), happiness (Lun \& Bond, 2013), less psychological distress (Chokkanathan, 2013) longevity and better mental health (Zimmer et al., 2016), higher psychological well-being (Momtaz, Hamid, Ibrahim, Yahaya, \& Chai, 2011) and it was inversely related to depression among older adults (Yoon \& Lee, 2007). While a majority of the studies have found the positive association between religion and well-being; however, few studies have reported null (Tran, Nguyen, Vu, \& Doan, 2017) and an inverse association between religiosity and welling (Brown \& Tierney, 2009) among older adults. Such equivocal research findings warrant further exploration.

Though, in the past decade, few researchers have thoroughly reviewed the literature regarding the relationship between religiosity and well-being among older adults. Koening (2009) reviewed religiosity in relation to psychiatric symptoms. In a recent review, Zimmer et al., (2016) inquired religiosity and spirituality as significant modifiable factors that contributed towards mental health and longevity. However, to the best of researcher knowledge, no study has systematically reviewed different aspects of religiosity with subjective wellbeing in older adult in one review. Taken into the account the aforementioned evidence, the current systematic review aimed to critically evaluate the existing literature in identifying literature gaps and underlying pathways between religiosity and subjective well-being in older adults.

\section{METHODOLOGY}

Electronic search through Google Scholar, Science direct and PubMed was conducted in May 2017 to identify potentially relevant published studies on the association between religiosity and subjective well-being among older adults. To maximize the amount of literature, the review included studies published from 2011 to May 2017, with the cross-sectional/comparative, cohort/longitudinal, qualitative, and quantitative research design. However, the review excluded studies that were not published peer-reviewed, the mean age of the sample was less than 60 years, theoretical papers without a sample, and papers without the English language. In addition, because of generalizability issues, studies conducted on the lesbian gay, non-human sample, immigrant samples, and experimental studies were excluded from the review. The keywords used for different constructs were 1) "elderly*" OR "aged parents*"
OR "older adults*" "religiosity*" OR "spirituality*" 8) "subjective well-being*" OR "positive affect*" OR "negative affect" OR "life satisfaction" OR "well-being*" OR "well-being*" OR "quality of life*". All these terms were sought out within titles and abstracts to ensure the large numbers of data was retrieved.

The literature selection procedure is described in figure 1. Initial screening of the title, abstract and full-text articles was undertaken by the author and counterchecked by another author. The main researcher extracted all data from three databases on the bases of the set criteria. In case of a disagreement about the inclusion of articles in the review, articles were reassessed until the agreement was reached. Two checklists namely; STrengthening the Reporting of Observational Studies in Epidemiology (STROBE, Von Elm et al., 2008) statements and Scottish Intercollegiate Guidelines Network (SIGN, 2001) have been applied for the quality assessment of the current review. The selected studies were systematically analyzed by focusing on research design, sampling technique, sample size, mean age, measures, results, and quality assessment, was presented in table 1. Detail synthesis of the selected studies has been done by exploring that whether the studies have explained the research objectives in a clear manner, using representative samples, adopted the appropriate methodology, accurately analyze the results and discussion.

\section{RESULTS}

The search strategy through three databases yielded 17034, which were screened by the research author for possible inclusion. After the screening for the peer-reviewed, English language, published during 2011 to March 2017, human sample and abstract, 77 articles were selected and examined in detail to determine eligibility. At the second step, 70 articles were excluded as 61 articles were not relevant, 1 was duplicate and 8 were not fully accessible (see Figure 1). At the final stage, 7 studies were thoroughly reviewed for possible literature gaps and underlying pathways. The findings of the current systematic review showed that 70 paper out of 77 were considered as not relevant because 1) these paper did not investigate the direct or indirect association of religiosity and subjective well-being 2) had the sample below the mean age of 60 years 3 ) outcome variable was not well-being 4) having experimental design, randomized control design or quasiexperimental designs 5) clinical population. 


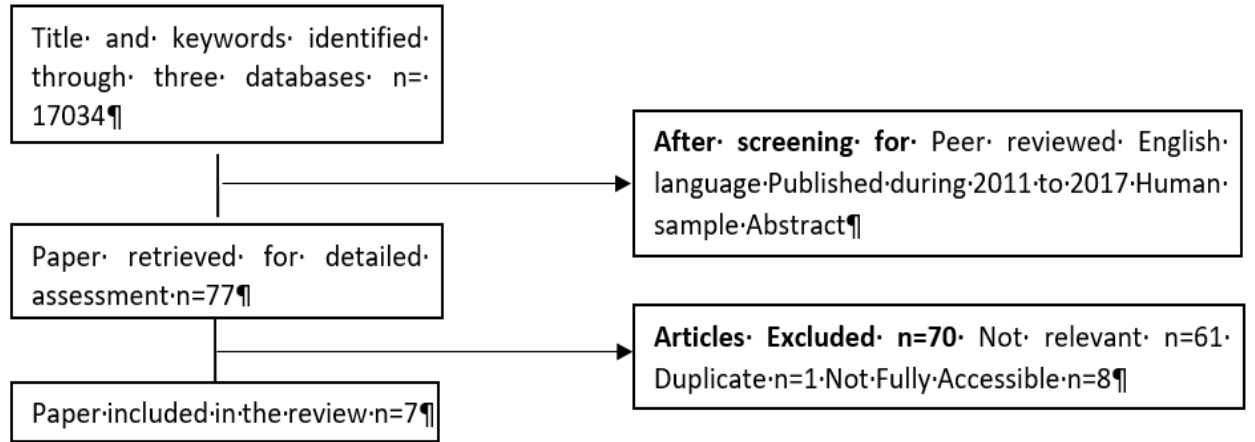

Figure 1: Flow Diagram of the Selection Process.

Table 1: Description of Studies about the Association between Religiosity and Subjective Well-Being

\begin{tabular}{|c|c|c|c|c|c|}
\hline $\begin{array}{l}\text { Author } \\
\& \\
\text { country }\end{array}$ & $\begin{array}{l}\text { Design/po } \\
\text { pulation } \\
\text { /sampling } \\
\text { technique }\end{array}$ & $\begin{array}{l}\text { Sample } \\
\text { character } \\
\text { istics }\end{array}$ & Measures & Results & $\begin{array}{l}\text { Quality } \\
\text { assessment }\end{array}$ \\
\hline $\begin{array}{l}\text { Marquine } \\
\text { et al., } \\
2015 \text {, } \\
\text { USA }\end{array}$ & $\begin{array}{l}\text { Cross } \\
\text { sectional } \\
\text { Communit } \\
\text { y dweller } \\
\text { Random } \\
\text { sampling }\end{array}$ & $\begin{array}{l}\text { Sample: } \\
252 \\
\text { Gender: } \\
57.9 \% \\
\text { male } \\
\text { Mean age: } \\
73\end{array}$ & $\begin{array}{l}\text { Satisfaction with Life Scale } \\
\text { Medical Outcome Study SF- } \\
36 \text { Cognitive Failures } \\
\text { Questionnaire Patient Health } \\
\text { Questionnaire-9 MacArthur } \\
\text { Scale of Subjective Social } \\
\text { Status Duke Social Support } \\
\text { Index-Social Interactions } \\
\text { subscale Emotional Support } \\
\text { Scale Santa Clara Brief } \\
\text { Compassion Scale optimism } \\
\text { Life Orientation Test-Revised } \\
\text { Connor-Davidson Resilience } \\
\text { Scale Multidimensional } \\
\text { Individual and Interpersonal } \\
\text { Resilience Measure Personal } \\
\text { Mastery Scale Brief Multi- } \\
\text { Dimensional Measure of } \\
\text { Religiousness/Spirituality }\end{array}$ & $\begin{array}{l}\text { Daily spiritual } \\
\text { experiences } \mathrm{r}= \\
-0.23 * * \quad \text { Private } \\
\text { religious practices } \mathrm{r}= \\
-0.14^{*} \text { Compassion } \mathrm{r} \\
=0.20^{* *} \text { Multivariate } \\
\text { analysis: } \mathrm{F}(4,217)= \\
5.29 * * * \text { Adj } \mathrm{R} 2=0.07 \\
\text { Meditational analysis: } \\
\text { Daily spirituality } 95 \% \\
\mathrm{CI}(0.19 \text { to } 1.15) \text { was } \\
\text { statistically } \\
\text { significant. } \\
\text { contrast, the paths } \\
\text { through religious } \\
\text { practices } 95 \% \mathrm{CI}=- \\
0.92 \text { to } .002) \text { and } \\
\text { compassion } 95 \% \mathrm{CI}= \\
-0.02 \text { to } 0.49) \text { were } \\
\text { not significant. }\end{array}$ & Moderate \\
\hline $\begin{array}{l}\text { Ronneber } \\
\mathrm{g} \text { et al., } \\
2016 \text {, }\end{array}$ & $\begin{array}{l}\text { Longitudi } \\
\text { nal } \\
\text { Communit } \\
\text { y dweller } \\
\text { Not } \\
\text { mentioned }\end{array}$ & $\begin{array}{l}\text { Sample: } \\
7,732 \\
\text { Gender: } \\
58.8 \% \\
\text { Mean age: } \\
68.12\end{array}$ & $\begin{array}{l}\text { Center of Epidemiological } \\
\text { Studies Depression scale } \\
\text { Leave-Behind Questionnaire } \\
\text { Religious affiliation, } \\
\text { organizational religiosity, } \\
\text { presence of both friends and } \\
\text { relatives in one's } \\
\text { congregation, rate the } \\
\text { importance of religiosity were } \\
\text { measured with five questions } \\
\text { developed by researcher }\end{array}$ & $\begin{array}{l}\text { Depressed at baseline } \\
\text { Religious affiliation } \\
\text { OR }=2.05^{*} \text { More } \\
\text { frequent engagement } \\
\text { in private Prayer OR } \\
=0.93^{*} \text { Non- } \\
\text { depressed at baseline } \\
\text { High service } \\
\text { attendance OR = } \\
0.65^{* *} \text { Low/no } \\
\text { service attendance } \\
\text { OR }=0.75^{*}\end{array}$ & Moderate \\
\hline
\end{tabular}




\begin{tabular}{|c|c|c|c|c|c|}
\hline $\begin{array}{l}\text { Mom } \\
\text { taz et } \\
\text { al., } \\
2012, \\
\text { Mala } \\
\text { ysia }\end{array}$ & $\begin{array}{l}\text { Cross } \\
\text { sectional } \\
\text { Community } \\
\text { dweller } \\
\text { Multistage } \\
\text { stratified } \\
\text { sampling }\end{array}$ & $\begin{array}{l}\text { Sample: } \\
1415 \\
\text { Gender: } \\
722 \text { female } \\
\text { Mean } \\
\text { age:70 }\end{array}$ & $\begin{array}{l}\text { Checklist chronic medical } \\
\text { conditions measure } 16 \\
\text { chronic conditions The } \\
\text { revised Intrinsic/Extrinsic } \\
\text { Religiosity WHO-5 Well- } \\
\text { Being Index }\end{array}$ & 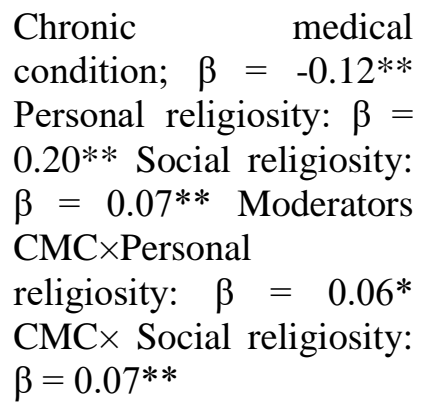 & Good \\
\hline $\begin{array}{l}\text { Rote } \\
\text { et al., } \\
2012 \text {, } \\
\text { USA }\end{array}$ & $\begin{array}{l}\text { Cross } \\
\text { sectional } \\
\text { Community } \\
\text { dweller } \\
\text { Probability } \\
\text { sampling }\end{array}$ & $\begin{array}{l}\text { Sample: } \\
2165 \\
\text { Gender: } \\
\text { 52\% female } \\
\text { Mean } \\
\text { age: } 69.10\end{array}$ & $\begin{array}{l}\text { Religious Attendance, } \\
\text { Social integration, \& Social } \\
\text { support were measures by } \\
\text { questions developed by } \\
\text { researchers } \\
\text { University of California, } \\
\text { Los Angeles Loneliness } \\
\text { Scale-R Epidemiologic } \\
\text { Studies CES-D }\end{array}$ & $\begin{array}{l}\text { Religious attendance with } \\
\text { Social integration: OR= } \\
.69 * \text { Religious attendance } \\
\text { with Social Support: OR= } \\
0.07 * * \quad \text { Religious } \\
\text { attendance with loneliness: } \\
\text { OR= - .0004 Social } \\
\text { integration with loneliness: } \\
\text { OR=-.003 Social support } \\
\text { with loneliness: OR= - } \\
.11^{* * *} \text { Meditational effect } \\
\text { Religious attendance on } \\
\text { loneliness through social } \\
\text { integration } \mathrm{z}=-2.16^{*} \\
\text { religious attendance on } \\
\text { social support through } \\
\text { social integration } \mathrm{z}=2.11^{*} \\
\text { religious attendance on } \\
\text { loneliness through social } \\
\text { support } \mathrm{z}=-3.23^{* *} \text { Social } \\
\text { integration on loneliness } \\
\text { through social support } \mathrm{z}=- \\
3.44 * *\end{array}$ & Moderate \\
\hline $\begin{array}{l}\text { Cole } \\
\text { man } \\
\text { et al., } \\
2011, \\
\text { Rom } \\
\text { ainia } \\
\& \\
\text { Bulg } \\
\text { aria }\end{array}$ & $\begin{array}{l}\text { Cross } \\
\text { sectional and } \\
\text { longitudinal } \\
\text { for Bulgarian } \\
\text { sample } \\
\text { Community } \\
\text { dweller Not } \\
\text { mentioned }\end{array}$ & $\begin{array}{l}\text { Sample: } \\
320 \\
\text { Gender: } \\
52 \% \text { female } \\
\text { Mean age: } \\
72 \\
\text { approximat } \\
\text { ely Follow } \\
\text { up with } \\
\text { Bulgarian } \\
\text { sample } \\
\text { Sample: } 58\end{array}$ & $\begin{array}{l}\text { Hospital Anxiety and } \\
\text { Depression Scale The Royal } \\
\text { Free Interview for Religious } \\
\text { \& Spiritual Beliefs Medical } \\
\text { Outcomes Study-Short } \\
\text { version The MOS Social } \\
\text { Support Survey Geriatric } \\
\text { Depression Scale Beliefs } \\
\text { and Values Scale } \\
\text { Multidimensional Measure } \\
\text { of } \\
\text { Religiousness/Spirituality }\end{array}$ & $\begin{array}{l}\text { Physical limitation } \beta= \\
0.30 * * * \text { Social support } \beta= \\
-0.26 * * * \text { Strength of belief } \\
\beta \quad-0.11 * * \\
\text { Country } \times \text { Strength } \beta=- \\
0.17 \text { Follow up with } \\
\text { Bulgarian sample } \\
\text { religious/spiritual coping } \\
\text { in 2007 r= } 0.33 * \\
\text { religious/spiritual coping } \\
\text { in } 2008 \mathrm{r}=0.12\end{array}$ & Weak \\
\hline $\begin{array}{l}\text { Poko } \\
\text { rski } \\
\& \\
\text { Warz } \\
\text { echa, } \\
2011, \\
\text { Polan } \\
\text { d }\end{array}$ & $\begin{array}{l}\text { Cross- } \\
\text { sectional } \\
\text { Community } \\
\text { dweller Not } \\
\text { mentioned }\end{array}$ & $\begin{array}{l}\text { Sample size } \\
34 \quad \text { Age } \\
\text { range: } 59- \\
86 \text { Gender: } \\
76 \% \text { female }\end{array}$ & $\begin{array}{l}\text { Center for Epidemiologic } \\
\text { studies Depression scale } \\
\text { (CES-D) Penn state Worry } \\
\text { Questionnaire (PSWQ) } \\
\text { General Health Questionnaire } \\
\text { (GHQ-12) Coping Inventory } \\
\text { for stressful situations (CISS) } \\
\text { Religious Commitment scale } \\
\text { (RCS) }\end{array}$ & $\begin{array}{l}\text { Health \& depression } \mathrm{r}= \\
.63^{* * *} \text { Worry } \\
\text { depression } \\
\mathrm{r}=.61 * * * \text { Religious } \\
\text { commitment \& depressive } \\
\mathrm{r}=\quad-\quad .03 \text { Religious } \\
\text { commitment in non- } \\
\text { depressive } \mathrm{r}=-.21\end{array}$ & Weak \\
\hline
\end{tabular}




\begin{tabular}{|llllll}
\hline Sun & Longitudinal & Sample: & The Geriatric Depression At baseline level Religious Mod & At \\
et al., & Community & 1,000 & Scale The Duke attendance $\beta=-.15^{* *}$ Prayer B= erate \\
2012, dweller & Mean & University Religion & .021 Intrinsic religiosity $\beta=-.013$ \\
USA & Stratified & age:75 & Index Social support & Quadratic effects Intrinsic \\
& random & Gender: & subscale of the Arthritis religiosity $\beta=-.021^{* *}$ Prayer $\beta=$. \\
& sampling & $50 \%$ & Impact Measure & 001 Religious attendance $\beta=.006$
\end{tabular}

\section{FINDINGS AND DISCUSSION OF THE SELECTED STUDIES}

Through literature search has found seven studies that highlighted the role of religiosity and spirituality among older adults along with several positive and negative outcomes. For instance, Rote, Hill and Ellison (2012) analyzed that religiosity characterized by religious attendance was inversely associated with loneliness among American older adults via social support and social integration. In a related study, Marquine et al., (2015) have found spirituality as a key factor that influences life satisfaction among Hispanic and non-Hispanic Whites. In addition, private religious practices and personality did not exert a significant impact on ethnicity and life satisfaction link.

Similarly, prospective studies in the United States also explained the protective role of the religion in relation to negative outcomes. Such as, Ronneberg, Miller, Dugan, and Porell (2016) have explored that non-depressed individuals at baseline who were frequently attended religious services were less likely to be depressed at 2 years follow up. In addition, depressive elderly at baseline have shown less depression after two years follow up when they were more engaged in the private prayers. Accordingly, Sun et al., (2012) found that different dimensions of the religiosity influenced depression differently. After controlling for the health, demographic and social resources the findings of the study revealed that religious attendance predicted lower depression at baseline level while intrinsic religiosity demonstrated a slight increase in depression over the period of four years. Non-organizational religiosity found to be uncorrelated.

Prospective and cross-sectional studies have highlighted the role of religious practices and beliefs in improving well-being in older adults. However, studies also explained the null association between religiosity and well-being. For example, Pokorski and Warzecha (2011) have investigated the effect of religiosity on affective distress among older Catholic believers in Poland. The findings reported a moderate level of religious activities and commitment but didn't suggest any significant difference of religiosity among the depressive and non-depressive sample.

Studies have also examined the link between religiosity and well-being among older adults cross-culturally. For example, Coleman (2011) found that country, age, gender, less physical limitation, social support and the strengths of religious beliefs were protective factors of depression. And lower levels of religious/spiritual beliefs are associated with higher depression among Bulgarian than Romanian sample in a crosssectional study. However, these patterns remained constant after 1 year follow up study among Bulgarian older adults. These findings were supported by findings from Malaysian older adults' sample where $17 \%$ of the variance in psychological well-being was accounted for by demographics, chronic medical condition, and religiosity. Among them, chronic medical condition, intrinsic and extrinsic religiosity were found to be stronger predictors of psychological well-being. The study also stated that the negative effect of chronic medical condition on psychological well-being was less severe for those older people who indulged in intrinsic and extrinsic religiosity (Momtaz, Hamid, Ibrahim, Yahaya \& Abdullah, 2012).

\section{CONCLUSION, LIMITATIONS, AND IMPLICATIONS}

Current studies have shown interesting findings on the similarities and differences in the association between religiosity and well-being in different cultures in older adults that warrant 
further exploration. Majority of studies have demonstrated that negative outcomes of religiosity in the older sample with less emphasize on positive indicators of well-being that required in-depth investigation. Religiosity is a multifaceted construct and there is lack of consensus on the clear definition of the religiosity. While many studies defined religiosity as religious attendance, practical religiosity or prayer whereas few have concentrated on intrinsic aspects of religiosity in association with subjective well-being. Future studies need to consider both intrinsic and extrinsic dimensions of religiosity in association with positive outcome.

The findings confirmed the positive association between religiosity and well-being but few have shown a null association between this link. Such equivocal results need further exploration. Similarly, much of the literature indicated the connection between religiosity and well-being, is descriptive in nature, as these studies only investigated the direct association, but the underlying mechanisms driving this association are unexplained. In addition, the review also revealed that most of the empirical evidence was from Western than non-Western cultural context.

The present systematic review has its limitations. First, the current systematic review included only those databases which were accessible. It might be possible that other databases have relevant studies and inclusion of these databases might provide enormous information regarding religiosity in association with the subjective well-being of older adults. The present review was restricted to peer-reviewed articles therefore, grey literature, conference papers, theoretical and conceptual papers were not included in the review this might affect the generalizability of review across the literature.

In gerontological literature, the field of religiosity in relation to subjective well-being is still growing. Taken into the consideration the knowledge and methodological gaps, some advancements are needed in order to fully comprehend the empirical connections between religiosity and subjective well-being among older person. This included the need to address different dimensions of religiosity in association with positive and negative aspects of well-being by using validated measures in non-Western cultures. The current knowledge will help scholars to fill literature gaps and thoroughly investigate the underlying pathways between religiosity and subjective well-being among older adults.

Acknowledgements Special gratitude to the National University of Science and Technology (NUST, Islamabad) for providing funding to scholar for attainment of $\mathrm{PhD}$ degree under FDP scholarship. Thanks to my research assistants who helped me during data collection.

\section{REFERENCES}

[1] Brown, P. H., \& Tierney, B. (2009). Religion and subjective well-being among the elderly in China. The Journal of Socio-Economics, 38(2), 310-319. https://doi.org/10.1016/j.socec.2008.07.014

[2] Chokkanathan, S. (2013). Religiosity and well-being of older adults in Chennai, India. Aging \& Mental Health, 17(7). https://doi.org/10.1080/13607863.2013.790924

[3] Coleman, P. G., Carare, R, O., Petrov, I., Forbes, E., Saigal, A., Spreadbury, J, H., Yap, A., \& Kendrick, T. (2011). Spiritual belief, social support, physical functioning and depression among older people in Bulgaria and Romania. Aging \& Mental Health, 15(3), 327-333. https://doi.org/10.1080/13607863.2010.519320

[4] Diener, E. (1984). Subjective well-being. Psychological Bulletin, 95, 542-575. https://doi.org/10.1037/00332909.95.3.542

[5] Diener, E., Oishi, S., \& Lucas, R. E. (2002). Subjective well-being: The science of happiness and life satisfaction. In C.R. Snyder \& S.J. Lopez (Ed.), Handbook of Positive Psychology. Oxford and New York : Oxford University Press.

[6] Gunnoe, M. L., \& Moore, K. A. (2002). Predictors of religiosity among youth aged 17-22: A longitudinal study of the national survey of children. Journal for the Scientific Study of Religion, 41(4), 613-622. https://doi.org/10.1111/1468-5906.00141

[7] Herero, V. G., \& Extremera, N. (2010). Daily life activities as mediators of the relationship between personality variables and subjective well-being among older adults. Personality and Individual Differences, 49(2), 124-129. https://doi.org/10.1016/j.paid.2010.03.019 
[8] Koenig, H. G. (2009). Research on religion, spirituality, and mental health: A review. Canadian Journal of Psychiatry, 54, 283-291. https://doi.org/10.1177/070674370905400502

[9] Krause, N. (2003). Religious meaning and subjective well-being in late life. The Journals of Gerontology Series B: Psychological Sciences and Social Sciences, 58, S160- S170. https://doi.org/10.1093/geronb/58.3.s160

[10] Lun, V. M. C., \& Bond, M. H. (2013). Examining the relation of religion and spirituality to subjective well-being across national cultures. Psychology of Religion and Spirituality, 5(4), 304. https://doi.org/10.1037/a0033641

[11] Marquine, M. J., Maldonado, Y., Zlatar, Z., Moore, R. C., Martin, A. S., Palmer, B. W., \& Jeste, D. V. (2015). Differences in life satisfaction among older community-dwelling Hispanics and non-Hispanic Whites. Aging \& mental health, 19(11), 978-988. https://doi.org/10.1080/13607863.2014.971706

[12] Momtaz, Y. A., Hamid, T. A., Ibrahim, R. Yahaya, N., \& Abdullah, S. S. (2012). Moderating effect of Islamic religiosity on the relationship between chronic medical conditions and psychological well-being among elderly. Psychogeriatrics, 12, 43-53. https://doi.org/10.1111/j.1479-8301.2011.00381.x

[13] Momtaz, Y. A., Hamid, T. A., Ibrahim, R., \& Chai, S.T. (2011). Moderating effect of religiosity on the relationship between social isolation and psychological well-being. Mental Health, Religion \& Culture, 14(2), 141-156. https://doi.org/10.1080/13674676.2010.497963

[14] Myers, D.G \& Diener, E.D. (1995). Who is happy? Psychological Science, 6(1), 10-19. https://doi.org/10.1111/j.1467-9280.1995.tb00298.x

[15] Peterson, T. L., Chatters, L. M., Taylor, R. J., \& Nguyen, A.W. (2014). Subjective well-being of older African Americans with DSM IV psychiatric disorders. Journal of Happiness Studies, 15(5), 1179-1196. https://doi.org/10.1007/s10902-013-9470-7

[16] Pokorski, M., \& Warzecha, A. (2011). Depression and religiosity in older age. European journal of medical research, 16(9), 401. https://doi.org/10.1186/2047-783x-16-9-401

[17] Ronneberg, C. R., Miller, E. A., Dugan, E., \& Porell, F. (2016). The protective effects of religiosity on depression: A 2-year prospective study. The Gerontologist, 56(3), 421-431. https://doi.org/10.1093/geront/gnu073

[18] Rote, S., Hill, T. D., \& Ellison, C. G. (2012). Religious attendance and loneliness in later life. The Gerontologist, 53(1), 39-50. https://doi.org/10.1093/geront/gns063

[19] Sun, F., Park, N. S., Roff, L. L., Klemmack, D. L., Parker, M., Koenig, H. G., \& Allman, R. M. (2012). Predicting the trajectories of depressive symptoms among southern community-dwelling older adults: The role of religiosity. Aging \& mental health, 16(2), 189-198. https://doi.org/10.1080/13607863.2011.602959

[20] Tran, T. Q., Nguyen, T. Q., \& Vu, H. V., \& Doan, T. T. (2017). Religiosity and Subjective Well-Being Among Old People: Evidence from a Transitional Country. Applied Research Quality Life, 12, 947-962. https://doi.org/10.1007/s11482-016-9500-9

[21] Tu, Y., \& Yang, Z. (2016). Self-control as mediator and moderator of the relationship between social support and subjective well-being among the Chinese elderly. Social Indicators Research, 126(2), 813-828. https://doi.org/10.1007/s11205-015-0911-z

[22] United Nations, (2017). World Population Prospects: The 2017 Revision, Key Findings and Advance Tables. Department of Economic and Social Affairs, Population Division. (ESA/P/WP/248). New York, USA. Retrieved from http://www.un.org/en/sections/issues-depth/ageing/.

[23] Von Elm, E., Altman, D. G., Egger, M., Pocock, S. J., Gotzsche, P. C., \& Vandenbroucke, J. P. (2008). The Strengthening the Reporting of Observational Studies in Epidemiology (STROBE) statement: guidelines for reporting observational studies. Preventive medicine, 45(4), 247-251. https://doi.org/10.1016/j.ypmed.2007.08.012

[24] World Health Organization (2016). Mental health and older adults. Retrieved from www.who.int/mediacentre/factsheets/fs381/en/.

[25] Yoon, D. P., \& Lee, E. K. (2007). The impact of religiousness, spirituality, and social support on psychological well-being among older adults in rural areas. Journal of Gerontology and Social Work, 48(3-4), 281-98 https://doi.org/10.1300/j083v48n03 01

[26] Zimmer, Z., Jagger, C., Chiu, C. T., Ofstedal, M. B., Rojo, F., \& Saito, Y. (2016). Spirituality, religiosity, aging and health in global perspective: A review. SSM-population health, 2, 373-381. https://doi.org/10.1016/j.ssmph.2016.04.009

(C) 2021 Sumara Masood U1 Hassan; Licensee ATSK Publishers.

This is an open access article licensed under the terms of the Creative Commons Attribution Non-Commercial License (http://creativecommons.org/licenses/by-nc/3.0/) which permits unrestricted, noncommercial use, distribution and reproduction in any medium, provided the work is properly cited. 